\title{
Revisiting Blackness, Slavery, and Jewishness in the Early Modern Sephardic Atlantic
}

\author{
Jonathan Schorsch
}

In their important 2011 book on the small Sephardic communities that existed in the early seventeenth century on the West African coast (today's Senegal), Peter Mark and José da Silva Horta discuss a Portuguese merchant whose success there enabled him to move to Amsterdam. Moisés de Mesquita (also known as António Lopes de Mesquita) indeed makes a fascinating figure. Seemingly born in Oporto, Portugal, he spent some years on the African coast as a young trader before arriving in Amsterdam by 1622. There he became wealthy enough to donate a Torah scroll to the Bet Israel synagogue in the 1630 s and was elected a parnas in 1647. Making De Mesquita's rise even more remarkable is the fact that he was a mulatto. ${ }^{1}$ Though drawing information from my 2004 book, Jews and Blacks in the Early Modern World, Mark and Horta pass over a fact I discussed there, though at the time I myself had been unaware of the background of De Mesquita that they uncovered. In light of Mark and Horta's research, what is for me one of the most noteworthy aspects of his time as parnas is that in that first year, 1647 , he signed off on an ascama (communal ordinance) creating a new, separate row in the Ouderkerk cemetery for the burial of non-Jewish blacks and mulattos. Only blacks and mulattos who were born to parents married according to Jewish law or who married a white Jew according to Jewish law would be permitted burial in the "regular" section of Ouderkerk. $^{2}$

Besides pointing up the need for scholars to learn from and communicate with each other, De Mesquita's example represents some of the complexities of race and religion in the early modern Sephardic Atlantic world. A mulatto who rose about as high as possible both economically and socially in the Amsterdam community, he supported as parnas the exclusion of blacks and

1 At least he was called a mulatto in an Inquisition document, which I have not yet examined directly. Peter Mark and José da Silva Horta, The Forgotten Diaspora:Jewish Communities in West Africa and the Making of the Atlantic World (New York: Cambridge University Press, 2011), 187, 211.

2 Jonathan Schorsch, Jews and Blacks in the Early Modern World (New York: Cambridge University Press, 2004), 196, 201.

(C) JONATHAN SCHORSCH, 2019 | DOI:10.1163/9789004392489_022

This is an open access chapter distributed under the terms of the prevailing CC-BY-NC License at the time of publication. 
mulattos if their Jewishness was not certified. This stance of course served to emphasize his own, presumably proper, Jewishness. Despite his racial status, he sided against other mulattos - and blacks - in favor of the religious norms of the community. Born as a New Christian, being able to vote as a parnas of the Amsterdam Spanish and Portuguese community to uphold "correct" Jewish practice must have felt like an irrevocable arrival. When it came to race, De Mesquita seems to have opted for Europe and a white community over the identity status and people of his black parent. De Mesquita's acceptance and rise within the Amsterdam community showed its relative openness to racial difference - as long as religious norms were upheld—at least in some cases. His signature to the 1647 ascama reflects the way race came to trump religious and halakhic (Jewish legal) values in other cases. His approval of the ascama may be read as a necessary ticket of admission for him; he could be part of the community-increasingly defined as white precisely through the promulgation of ordinances such as this one-if he adhered to its standards, which two decades earlier had begun wielding the language of religion as a means of minimizing the intrusion of non-whites.

In the thirteen years since my book was published, a number of scholars have produced further work on the subject, supplementing and in some cases correcting my findings. In this essay I want to do two things. First, I will highlight the most salient insights from the important and growing body of new work on the Sephardic Atlantic world. ${ }^{3}$ Since most of this new research focuses on specific locales or even individuals, frequently content to remain on the level of the anecdote, I will put its findings into a multi-locational and diachronic Atlantic-world perspective, a necessary step to correct what I feel are the too-often myopic and unsystematic conclusions drawn by these scholars. Race as a governing strategy and social structuration always reflects ambivalence. Too often, even these intelligent, recent investigations seek to resolve the ambiguity of racism by imagining that moments of inclusion erase moments of exclusion. Second, I will summarize the religious issues at work shaping and responding to slavery and race as a central aspect of the Western Sephardic experience in the fifteenth to eighteenth centuries.

We must start with the Portuguese excursions to the western coast of Africa in the fifteenth century. As recent research has shown, New Christians and Sephardim were intimately involved with this overseas expansion, the real beginning of the Atlantic mercantile and colonial system. In a short span of time,

3 I should rightfully include here Iris Idelson-Shein, Difference of a Different Kind: Constructions of Race During the Long Eighteenth Century (Philadelphia: University of Pennsylvania Press, 2014), but since it focuses on Ashkenazic domains I leave it aside. 
Tobias Green has produced one of the most sophisticated and well-researched bodies of literature on the commercial, theo-political, and cultural role of the Portuguese along the West African coast. ${ }^{4} \mathrm{He}$ expertly delves into African perspectives and sources, adding a welcome dialogical lens to the usually solely Western-oriented story.

Beginning with Green's doctoral dissertation on the New Christians of Cape Verde from the late fifteenth through the late seventeenth century, he shows that because the Portuguese and Spanish monarchs opted to continue relying on New Christian merchants the way they had previously relied on Jewish traders, New Christian activities on the West African coast helped forge the wider Atlantic-world commercial and settlement efforts of the far-flung Portuguese networks. Because of their familiarity with and openness to cultural crossing, New Christians were key to intra-African trade and the process of creolization that it spawned. On the mainland, where local societies had long been accustomed to cultural mingling by and with outside traders, New Christians, also used to cultural bricolage due to their own troubled history, were willing to marry African leaders' daughters in order to create alliances and acted as cultural intermediaries, even adopting some of their spouses' host cultural practices. Green sees this New Christian behavior as a subversion of dominant Portuguese attitudes and norms, intentionally or not, and part of what led to their being perceived as a threat. Yet New Christians, including the extended Gramaxo family on which Green focuses in several studies, were also very active in Cape Verdean and inland slave trading from the early sixteenth century. Racialized social and theo-political hierarchies and structures arose rather quickly on Cape Verde and elsewhere, excluding or marginalizing blacks, and positioning mixed-race individuals and New Christians in differing but parallel ways as not quite fully white and Christian. From the beginning of this phase of the Portuguese-African encounter, then, we see a complex, often contradictory set of relationships, in which New Christians played a central role.

Parallel to and continuing Green's explorations, Peter Mark and José da Silva Horta's research, culminating in their book, presents a fascinating and noteworthy study of several communities in West Africa where Portuguese conversos and Portuguese Jews from the Netherlands lived and traded in the late sixteenth and early seventeenth centuries. Joal, Porto d'Ale and Rufisque,

4 See, among his other writings, Tobias Green, "Masters of Difference: Creolization and the Jewish Presence in Cabo Verde, 1497-1672," PhD diss., Centre of West African Studies, University of Birmingham, 2006; Green, "Equal Partners? Proselytising by Africans and Jews in the 17th Century Atlantic Diaspora," Melilah 1 (2008): 1-12; id., The Rise of the Trans-Atlantic Slave Trade in Western Africa, 1300-1589 (Cambridge: Cambridge University Press, 2011). 
ports under Wolof or Wolof-Serer control in coastal Senegambia, as well as Cacheu further south, comprised thriving commercial beachheads of trade between Europe and West Africa, run for the most part by a network of stillChristian conversos and practicing Jews often linked by family ties, some of the latter perhaps derived from New Christians inhabiting Guinea and seemingly openly practicing Judaism there as of the late sixteenth century. Each community seems to have had its own prayer house, enough people to form a minyan and practiced circumcision and kosher slaughtering of meat. The authors suggest that some of the original trader-settlers were the mulatto offspring of New Christians/Sephardic Jews and African women in Portugal, returning to a place where their maternal family connections provided them socio-economic advantage.

Hoping to correct scholarly misimpressions, the authors, specialists in the early modern Portuguese empire and West Africa, argue that the Sephardic diaspora's conversionary and inquisitional oppression forced New Christians and Sephardic Jews to help create the Portuguese Atlantic world; that these Jewish and New Christian merchants and settlers converted and married locals, influenced local Africans, and helped forge a distinctive, in some ways syncretic religious life; and, as is argued by Green, that the broader cultural syncretism brought about by the European presence in West Africa resulted at least in part from Sephardic patterns of social and commercial behavior based on flexible identity generated by the needs of survival.

These were tiny communities, as were almost all such mercantile outposts in the incipient overseas colonies, numbering at their peak perhaps thirty households. Beginning in the 1620s, many of the Jews returned to Amsterdam, having made enough money through trade to do so. The possibility of living openly in the region as a Jew seems to have diminished by the 1630 , due to new, more pro-Portuguese rulers, meaning that the life span of these communities comprised some few decades at most (active Portuguese investigation of these communities commenced only in 1610).

The initial New Christian/Sephardic openness toward alliances with Africans, relations with African women, and inclusion of mixed-race children in the community conforms to the traditional halakhic attitude: as long as the entry procedures are followed, anyone can join the community. ${ }^{5}$ Green, Mark, Horta, along with José Alberto Rodrigues da Silva Tavim, believe that

5 I argued that this attitude seems to have reigned until around the sixteenth century in Schorsch, Jews and Blacks in the Early Modern World, chaps. 3 and 7. 
conversion of Africans and slaves may even have constituted an intentional strategy. ${ }^{6}$ Green, Mark, and Horta use the evidence of such marriages, conversion of offspring and slaves and commercial interaction to argue that New Christians/Sephardim showed a unique openness toward Africans; Green has written that converting Africans was "implicitly — [to] rebel against the developing worldview of Africans emerging in Europe"; ${ }^{7}$ and Mark and Horta argue that race did not exist as a factor in West Africa.

I find it difficult to accept all of these conclusions. Openness to relationships with African women likely stemmed from instrumental motivations and itself hardly negates the fact that Jewish discourse shared already from at least the Middle Ages in a general Muslim/Arab and European/Christian denigration of blackness, even if it was not monolithic. Contrarily, attraction to the exotic Other is frequent, though it does not necessarily eradicate the discursive structures (such as race) that construct the Other as exotic. While convincingly positing a kind of West African non-racial multiculturalism, at least initially, it seems odd that Green, Mark, and Horta barely acknowledge that New Christians and Sephardim might have brought their own convictions with them as outsiders and that their attitude was not only a race-or ethnicityblind openness. As I discuss later, and as Green acknowledges, most of these New Christians, obviously, and even Sephardim likely were not particularly religiously scrupulous. I agree that conversion of free Africans, African slaves, and mixed-race offspring may have been a strategy: a pragmatic choice in remote regions where the communities were minuscule and vulnerable, little more than factories in the original early modern sense of the term; commercial outposts, surrounded by the native population, on which they were nearly completely dependent. The women they had relations with or married were not slaves, it must be kept in mind. New bodies offered a welcome strengthening of the community. The anecdotal evidence of such conversions does not convince me that any "missionary" or expansionist program was at work, except in the minds of some individuals, who were possibly following the

6 Peter Mark and José da Silva Horta, "Catholics, Jews, and Muslims in Early SeventeenthCentury Guiné," Atlantic Diasporas:Jews, Conversos, and Crypto-Jews in the Age of Mercantilism, 1500-180o, ed. Richard L. Kagan and Philip D. Morgan (Baltimore: Johns Hopkins University Press, 2009), 293; José Alberto Rodrigues da Silva Tavim, "Galut and Empire: On the Way to the Final Redemption," The Sephardic Atlantic: Colonial Histories and Postcolonial Perspectives, ed. Sina Rauschenbach and Jonathan Schorsch (New York: Palgrave, forthcoming).

7 Tobias Green, "Amsterdam and the African Atlantic: The Role of Amsterdam Sephardim in Senegal in the Early Seventeenth Century," Proceedings of the Fourteenth British Conference on Judeo-Spanish Studies (26-28 June 20o6), ed. Hilary Pomeroy, Christopher J. Pountain and Elena Romero (Dept. of Hispanic Studies, Queen Mary, University of London, 2008), 93. 
traditional halakhic mandate, which itself comprised an age-old absorptionist mechanism operating on a liminal population of partial insiders, slaves. If anything, the openness of Africans to conversion and the conversions or absorptions themselves acted as a psychological salve and form of one-upmanship for subaltern New Christians/Sephardim against Christian denigration and persecution.

If New Christians/Sephardim evinced a uniquely open attitude toward Africans these scholars need to explain the numerous conversions of Africans to Catholicism at the same time, the marriages of Portuguese to African women (which scholars suggest was far more frequent among the lower classes), and the acceptance of some manumitted slaves into Portuguese and Spanish society. Despite some of his own arguments, Green's findings regarding New Christian slave trading itself rebut the notion that New Christians were characterologically or culturally egalitarian when it came to Africans. Most problematic, to my mind, is that Mark and Horta seem unwilling to recognize that the openness that made functional sense within and took advantage of the religious freedom along the West African coast led to a strong backlash in Amsterdam in the form of a series of ascamot excluding blacks and mulattos from or restricting them within Jewish communal life there. This decadeslong racially-based exclusionary campaign, which spread beyond Amsterdam to other Sephardic communities in the Caribbean, is dialectically related to patterns in West Africa; it is part of the same story. Local specificities do not negate regional or cis-atlantic patterns; both must be taken into account.

The first ascamot promulgated in Amsterdam in the early seventeenth century wielded the language of halakha. (Below I provide a list of all of the communal legislation pertaining to blacks and mulattos from around the Sephardic Atlantic.) Blacks and mulattos who were not born Jewish or properly converted were excluded from or restricted within communal life. This leads me to believe that many of the black and mixed-race individuals coming from the West African coast or arriving with their New Jewish families were not circumcised or converted according to halakha, contra Mark and Horta. The ascamot quickly came to prohibit or restrict non-whites as such, showing a racialist orientation that co-mingled with and at times surpassed halakhic worries. The backlash in Amsterdam against the Africans and mixed-race individuals is palpable. It likely reflects the difference between the relatively open Portuguese attitude toward race and race-mixing and the seemingly more disinterested Dutch approach, as well as between colony and metropole.

In the mid-seventeenth century, due to the fall of Dutch Brazil and new conquests by the Dutch and English in the Caribbean, Sephardic colonial life shifted to the Caribbean. Fresh research by Aviva Ben-Ur, Natalie Zemon Davis, 
Wieke Vink and others has turned up a multitude of new details regarding daily life in the slave and plantation society of Suriname, the single most developed such socio-economic arrangement among Jews, as well as elsewhere. Based on terrific investigation of archival records and informed by developments in studies of slavery, colonization, the Atlantic world, creolization, and the like, these investigations into the Sephardic Caribbean present key new information and offer critical nuance to the portrait of blackness in the Sephardic Caribbean.

In a series of essays, Aviv Ben-Ur has published a great amount of new material that she has dug up on the lives of the Surinamese Sephardim, their slave women, and the mixed-race individuals born when members of these two groups had sex, coerced or not, or romances. ${ }^{8}$ Arguing against my minimization of mixed-race Jewish numbers (she cites me explicitly), Ben-Ur claims that by the second half of the eighteenth century, due to natural growth, there existed "around 100 Jewish Eurafricans in each generation" positing that ten percent of the Jewish community was Eurafrican "by the second half of the eighteenth century." ${ }^{\prime 2}$ Many of these mixed-race individuals were raised as Jews, acknowledged as children by their fathers, became involved in Jewish communal and religious life, took on their masters' names and sometimes businesses, even inheriting family property. We see the efforts, often successful, that slave women and colored Jews exerted to look out for their own interests, enter into the Jewish community, create support networks, and play the various forces in the colony against one another to their own advantage. Throughout her publications, but particularly in an essay on the cultural heritage of what she calls (following George F. Brooks) "Eurafrican" Surinamese

8 Aviva Ben-Ur, "The Cultural Heritage of Eurafrican Sephardi Jews in Suriname," The Jewish Diaspora in the Caribbean, ed. Jane S. Gerber (Oxford: Littman Library of Jewish Civilization, 2013), 169-93; "A Matriarchal Matter: Slavery, Conversion, and Upward Mobility in Suriname's Jewish Community," Atlantic Diasporas: Jews, Conversos, and Crypto-Jews in the Age of Mercantilism, 1500-180o, ed. Richard L. Kagan and Philip D. Morgan (Baltimore: The Johns Hopkins University Press, 2009), 152-69; "Peripheral Inclusion: Communal Belonging in Suriname's Sephardic Community," Religion, Gender, and Culture in the Pre-Modern World, ed. Alexandra Cuffel and Brian Britt (New York: Palgrave Macmillan, 2007), 185-210; "Still Life: Sephardi, Ashkenazi, and West African Art and Form in Suriname's Jewish Cemeteries," American Jewish History 92, no. 1 (2004): 31-79.

9 Aviva Ben-Ur and Jessica V. Roitman, "Adultery Here and There: Crossing Sexual Boundaries in the Dutch Jewish Atlantic," Dutch Atlantic Connections, 1680-180o: Linking Empires, Bridging Borders, ed. Gert Oostindie and Jessica V. Roitman (Leiden: Brill, 2014), 205. In an earlier study, "Matriarchal Matters," she had estimated the Eurafrican Jewish population at seven percent, while elsewhere, she sets the number at 7.2 percent (Ben-Ur, "Cultural Heritage," 172; "Peripheral Exclusion," 199). It seems Ben-Ur has revised her estimates upward over time. 
Jews, she shows that inclusion in the community frequently defied halakhic norms, while Jewishness constituted an "ethno-religious, rather than a religious identity."10 Ben-Ur rightfully notes that even today there is much left to uncover regarding the lives of mixed-race Jews in the Sephardic Atlantic world.

Ben-Ur provides rich data on the lives and culture of Eurafrican Jews. She argues that Eurafricans increasingly inherited Jewish culture and identity from their mothers, who had been born Jewish. ${ }^{11}$ Mixed-race Jews partook of many aspects of Jewishness "besides 'religion'-language, name-giving practices, historical consciousness, and identification with the Jewish people, both locally and remotely."12 Expanding on the research of Robert Cohen and others, Ben-Ur traces the brotherhood set up by the mixed-race Jews in 1759, later transformed into a prayer house, showing that by this time they had developed their own parallel community and ritual practice. For decades they continued to face denigration and marginalization from the white Sephardic leadership, however, despite what might have been sympathy with their cause. Finally, after a series of conflicts between the two segments of the community in the 1780 s and 9os, the white Sephardic leadership in 1793 curtailed various privileges of the mixed-race group. ${ }^{13}$ In her essay on the cemeteries of Suriname, Ben-Ur speculates on how various Jewish visual symbols on tombstones and elsewhere might have resonated with similar symbols from West Africa, and notes the appearance on wooden grave markers in the cemeteries where mixed-race free individuals - some Jewish — were buried as of the nineteenth century, of heart-shaped symbols of probable Akan provenance (the background of many slaves who ended up in the colony). In some cases, again all from the nineteenth century or later, Jewish and creole symbols were both chosen to decorate a grave marker. Clearly, Jewish authorities permitted the use of such visual imagery.

In an essay co-written with Jessica Roitman, we see that daily life in the eighteenth- and nineteenth-century cities showed much interaction across racial boundaries. Intimacy, friendships, trust, alliances, and knowledge bound together white Jews with free people of color and even slaves. ${ }^{14}$ Such coexistence has to be measured against the aptly-named "peripheral inclusion" (BenUr's term) that non-whites faced. In the Jodensavanne cemetery, the majority

\footnotetext{
10 Ben-Ur, "Cultural Heritage," 170. Here, as well, Ben-Ur is arguing against me by using David Biale's call for use of the term "Jewish culture," rather than "Judaism."

11 Especially in Ben-Ur, "Cultural Heritage."

12 Ibid., 192.

13 Ben-Ur, "Peripheral Inclusion," 192-94.

14 Ben-Ur and Roitman, "Adultery Here and There," 185-223.
} 
of non-whites were buried clustered in the "extreme north-east corner."15 As I also had shown in my book, Eurafrican Jewish children were frequently given biblical or Jewish names, but not ones usually used by white Jews and thus "set their bearers apart from mainstream Portuguese Jews even as they connected them to the broader Sephardic community."16 In the nineteenth century exclusion began to wither, in part due to challenges by the mixed-race Jews. By 1802, racial distinctions were no longer enforced when it came to "pious deeds" connected to burial. As of 1820 , rows in the cemeteries were no longer dedicated to specific classes of people. ${ }^{17}$

In recent years the gifted and prominent historian Natalie Zemon Davis has turned her attention to Suriname and its Portuguese Jewish community. A series of thorough, insightful, and often revelatory essays, based on Davis's usual prodigious research skills, comprise the building blocks of her still-awaited promised study, Braided Histories: Slavery and Sociability in Colonial Suriname. ${ }^{18}$

Treating seventeenth-century phenomena, Davis offers a powerful depiction of the imagined and discursive place of slavery in Sephardic colonization. She speculates that the fact that so many African male slaves arrived circumcised "must have eased the worry of those Jews [in Dutch Brazil] who took seriously the biblical and halakhic requirement of circumcision." ${ }^{19}$ In a noteworthy find, she discovered that Amsterdam Rabbi David Pardo recommended in his 1689 Spanish-language survey of laws Sephardic Jews should follow that plantation owners, in order to "complete" the African circumcisions of their slaves, need merely take a drop of blood, as halakhically required.

A wonderful micro-study of David Nassy (also spelled Nassi), perhaps the elite Portuguese Jewish planter best known to scholars, reveals him expressing the sentiments typical of an ameliorationist. As late as 1795, after three years in Philadelphia and even in the company of mostly Quaker abolitionists, he denied liberty and equality to Blacks, since, he felt, being uncivilized,

15 Ben-Ur, "Cultural Heritage," 171.

16 Ibid., $173-74$.

17 Ben-Ur, "Peripheral Exclusion," 197.

18 Natalie Zemon Davis, "Regaining Jerusalem: Eschatology and Slavery in Jewish Colonization in Seventeenth-Century Suriname," The Cambridge Journal of Postcolonial Literary Inquiry 3, no. 1 (January 2016): 11-38; “Judges, Masters, Diviners: Slaves' Experience of Criminal Justice in Colonial Suriname," Law and History Review 29, no. 4 (November 2011): 925-84; "David Nassy's 'Furlough' and the Slave Mattheus," New Essays in American Jewish History, Commemorating the Sixtieth Anniversary of the Founding of the American Jewish Archives (Cincinnati: American Jewish Archives, 2010), 79-93; "Creole Languages and Their Uses: The Example of Colonial Suriname," Historical Research 82, no. 216 (May 2009): 268-84.

19 Davis, "Regaining Jerusalem," 16. 
they would only serve as negative temptations. Yet he urged masters not to mete out "horrible punishments" to their slaves, but rather offer proper care, in order to prolong their lives and increase their birth rate. ${ }^{20}$ While proper care for slaves in a cruel slave society reflected a call for humane treatment, his concern for slaves' birth rate evinces a concern for the master's commercial wellbeing: more slaves, being his property, means more bodies available for labor or profitable sale. These attitudes informed his demeanor toward the mixedrace Jews in the Portuguese Jewish community. The Enlightenment-influenced Nassy's 1789 reforms of the ascamot, intended to modernize the community's self-governance, made no changes to the rules that kept mixed-race individuals as lesser congreganten and not full members, jehidim, while also insisting on humiliating seating arrangements for them in synagogue. ${ }^{21}$ Yet on a personal level, as an owner of slaves and as plantation owner for a time, in the 1770s Nassy treated his slaves relatively well. Three mulatto slaves, Moses, Ishmael, and Isaac, were all circumcised, brought into Judaism and eventually manumitted. A medical man, Nassy tended to the skin disease of the young slave Mattheus, carpenter and personal attendant, whom he rented and then purchased, looking out for him in general due to Mattheus's good service and loyalty.

During his three years in Philadelphia, from 1792, he came to know the two Quaker-connected, pro-abolitionist Jews at the Mikveh Israel congregation. Nassy freed Mattheus and his own daughter Sarah's ten-year-old slave girl Amina in Philadelphia, maintaining them both as indentured servants for the next seven years in Mattheus's case and eighteen years in the girl's case. While these acts may reflect Nassy's magnanimity, they were law in Pennsylvania. ${ }^{22}$ In a letter from 1795 Nassy wrote of them as part of his family. Mattheus chose not to remain in the United States, returning with Nassy, possibly because he had his own family in Suriname, possibly out of devotion, even affection for his patron and protector. In 1796, back in Suriname, Nassy proposed establishing a college open to boys of all backgrounds, if they were free, seemingly including non-whites, since Nassy's prospectus mentions no prohibition on colored applicants. Mattheus's fate in Suriname remains unknown, but his name does

20 Davis, "Judges, Masters, Diviners," 976. She is citing David Nassy, Memoire sur les moyens d'ameliorer la Colonie de Suriname (ms., 1795), 232-35, 30-31. The words in quotes come directly (in translation) from the text. Davis, "David Nassy's 'Furlough' and the Slave Mattheus," 89 .

21 Ibid., 82.

22 Ibid., 88. 
not appear as one of the colored congreganten. Indeed, it is not at all clear from the evidence Davis cites that he even considered himself Jewish. ${ }^{23}$

Davis has added to evidence regarding Sabbath observance when she discovered that a 1707 slave uprising at Palmeniribo, which was adjacent to Jewish plantations, may have had as one of its contributing factors the resentment felt by the plantation's slaves, owned by non-Jews, that the slaves on nearby plantations owned by Jews had Saturday off as well as Sunday. ${ }^{24}$ Davis also came across "evidence that the rulings of the Mahamad in regard to the cessation of work on the Sabbath and the specified feast days were respected" in the "rare diary of Samuel Bueno Bibaz, manager of a coffee plantation in 1743-1744."25 Although we have little evidence until later in the eighteenth century, Davis infers from the fact that some of the Portuguese Jewish elite of Jodensavanne had the loyalty of many slaves in fighting against the Maroons, both defending against them on their own plantations and also being willing to venture out on sorties against them in the bush, that it "is one of the possible signs of a plantation conducted in a fashion at least tolerable to its workers." ${ }^{26}$

Wieke Vink has written probably the most important book to date on Jewish Suriname, Creole Jews. ${ }^{27}$ She has provided the fullest picture so far of the history of the Sephardic community there as a multi-racial society (she also deals with the Ashkenazic community, but I will not treat that here). With ample evidence from the sources and analysis attuned to communal and colonial politics, Vink explores the ambivalence of white Sephardim toward both slave and free, black and mixed-race individuals. Vink, who works outside of Jewish Studies, corrects for some of the biases often evinced by Jewish scholars (understanding the latter in terms of institutional and communal subject position), offering a corrective to the continued scholarly lightening of the Jewish settlements' darker aspects.

Vink describes the twists and turns of a fledgling and vulnerable community, growing in size, power, and wealth, its decidedly non-linear history of inclusion and exclusion of non-whites, its repeated efforts to set boundaries and enforce identity. She gives us a thorough explanation of the history of Darhe Jesarim (Paths of the Righteous), the study group then congregation of the mixed-race Jews. Originally established by white Sephardim, who obviously

\footnotetext{
23 All the above from Davis, "David Nassy's 'Furlough' and the Slave Mattheus."

24 Davis, "Judges, Masters, Diviners," 952-53, n. 67.

25 National Archief, The Hague, Archief der Nederlands-Portugees-Israelitische Gemeente in Suriname, inv. 493.

26 Davis, "Judges, Masters, Diviners," 945.

27 Wieke Vink, Creole Jews: Negotiating Community in Colonial Suriname (Leiden: KITLV Press, 2010).
} 
wanted the mixed-race Jews out of their own white congregation, they later essentially regulated it out of existence.

Like Ben-Ur, Vink shows us a history of conflicting impulses. Despite restrictions on non-white Jews, in the late eighteenth century the parnassim admitted every request "to admit a certain 'free mulatto' or 'slave bought for freedom"” as a congregant, despite the absence of a Jewish mother. The only "requirement for admission was a basic understanding of Jewish law and custom." 28 This inclusiveness likely was generated by the economic crisis in the colony and the rapid and severe decline of the Sephardic community. Yet this inclusiveness led to even further restrictions.

As Vink shows, in the nineteenth century, as creolization and racial mixture increased, the Sephardic community followed suit. In the years that followed the abolition of discrimination "the number of requests by coloureds to be admitted as congregants tripled." Between 1830 and 1840 , "an estimated 35 to 50 requests were made for the admittance of coloureds or manumitted slaves as congregants in either the Portuguese or the High German community. Moreover, the number of slave requests for admittance increased." Yet this does not mean race ceased to signify. Indeed, now that equality reigned within the community far fewer non-whites were accepted. ${ }^{29}$ Her depiction differs significantly from Ben-Ur's claim that black and mixed-race Jews found admission.

I hope that even my inadequate survey makes clear that this new research has greatly expanded our knowledge about blacks, mixed-race individuals and whites in the Sephardic Atlantic world. ${ }^{30}$ Several problems arise for me from this recent work, however. Too many scholars remain within the realm of synchronic, local anecdotal narratives. Nonetheless, we now collectively know enough to see the movements toward inclusion and exclusion both geographically, temporally, and socio-politically.

While fascinating and important, the existence and experiences of colored Jews seems to me greatly overplayed by Jewish scholars. First there is the

28 Ibid., 225 .

29 Ibid., 241.

30 Other significant contributions include Stanley Mirvis, "Sexuality and Sentiment: Concubinage and the Sephardi Family in Late Eighteenth-Century Jamaica," The Jews in the Caribbean, ed. Jane S. Gerber (Oxford: Littman Library of Jewish Civilization, 2011), 223-40; Karl Watson, "Shifting Identities: Religion, Race, and Creolization among the Sephardi Jews of Barbados, 1654-1900," in Gerber, ed., Jews in the Caribbean, 195-222; Jackie Ranston, Belisario: Sketches of Character: A Historical Biography of a Jamaican Artist (Kingston: The Mill Press, 2008); Tim Barringer, Gilliam Forrester and Barbara MartinezRuiz, eds., Art and Emancipation in Jamaica: Isaac Mendes Belisario and His Worlds (New Haven: Yale University Center for British Art/Yale University Press, 2007). 
matter of numbers. Vink agrees with Ben-Ur that, at least regarding the late eighteenth century, up to ten percent of the Sephardic community was black or mixed-race. However, she finds that in the nineteenth century this ratio declined to around five percent, a far smaller proportion than existed among Protestants (excluding Moravians), which by then reached an incredible sixtyfour percent. ${ }^{31}$

Then there is the question of interpreting the persistent racial tensions. Like too many Jewish scholars, Ben-Ur consistently inclines toward emphasizing inclusion and coexistence over exclusion and conflict. The Bush Negro (Maroon) plates possessed in the early nineteenth century by one Sephardic resident of Jodensavanne "reflect the Jewish community's receptivity to Afro-Suriname influences." ${ }^{32}$ From her own research I see few examples of such influences accepted by the community. She calls the mixed-race "community" "small but influential."33 Such influence far more often than not was resisted by the white Sephardic authorities.

I fully agree with Ben-Ur that the white Surinamese Sephardim stopped following halakha when it came to their slaves and the conversion of non-whites. That was one of the main arguments of my 2004 book. While Jewishness now meant more than halakhic Judaism, white Sephardim and black and mixedrace Sephardim did not seem to agree on what it meant. Ben-Ur traces the conflicts but without addressing the substantive differences. Until late in the nineteenth century, if even then, black and mixed-race Jews were almost never seen as equals and, with so few exceptions that they easily can be counted, most were relegated to second-class status in the community in general and in the religious life around which the community revolved. The limitations placed on them-restricting their choices in marriage, burial, ritual practice, etc. - were real and persistent and must have generated great pain and resentment (we see this boil over in the late eighteenth century). Ben-Ur wants to see colored Jews as fully Jewish, even if not halakhically so, but much of the community itself persistently and successfully worked to limit their rights and status as Jews.

One must also keep in mind the overall context in which the mixed-race Jews arose and struggled. No one denies that these individuals were Jewish, as Ben-Ur asserts (probably with me in mind); what troubles me is that the overwhelming number of slaves belonging to Jews were not made Jewish in any fashion and Ben-Ur consistently ignores this non-assimilation of the overwhelming

31 Vink, Creole Jews, 256.

32 Ben-Ur, "Still Life," 78.

33 Ibid., 36. 
majority of slaves. Colored Jews made up a very small minority of the blacks and mixed-race slaves subject to Sephardic domination-I calculated two percent, but let's say it is even higher. I do not believe that there is a single study of hers where she explores this context. Even if it is true that ten percent of Surinamese Sephardim were mixed-race at some points, she never attends to the other ninety percent of blacks and mixed-race people within the Sephardic sphere! Her emphasis is always on the statistically marginal number of slaves and emancipated slaves who affiliated with the Jewish community. I see two reasons for this: (1) documentation seems to be more plentiful and multidimensional; (2) ideological bias toward a narrative that reflects less negatively on Jews.

Another enormous lacuna, to my mind related to the over-determined question of "colored" Jews, is the question of power and agency. Ben-Ur and Davis insist on complicating concepts such as slavery and race, focusing on interpersonal mutuality, the multi-directionality of agency and contestation of systemic structures from below. While all this is welcome and vital, I sense a deep, recurring unwillingness to acknowledge that while slavery dominated as the socio-political structure, very real inequality pervaded everything: religious life, economic opportunities, personal relations, rights and freedoms. White Sephardim possessed and wielded far greater agency than their black and mixed-race slaves or freed individuals, even when the latter were Jewish. Particularly in Ben-Ur's work, descriptions of slavery among Sephardim, which differed hardly at all from the general tenor of the Caribbean slave system, are mostly anodyne, neutral to the point of avoidance. She devotes next to no analytical energy to Sephardic slave masters, plantation management, participation in the internal colonial slave trade or absence from abolitionism.

The second area of confusion is the question of religion. Ben-Ur and, to a lesser degree, Davis want things both ways. We are to believe that the Surinamese Sephardim named their synagogue after a passage in the Zohar and were kabbalistically-inclined, but didn't follow halakha regarding transmission of Jewish status or many elements of treatment of slaves. Judaism was no longer central to identity, but colored Jews were ritually made Jewish. Jewishness was a question of "civilization" and not "religion," Ben-Ur argues, but her own evidence shows that the Jewish authorities frequently marginalized colored Jews in much of this non-religious sphere as well and, with few exceptions, accepted the colony's racialized structures. Despite Judaism's supposed loss of prominence as a determinant of categories, almost all of the most documented tensions between white and colored Jews revolved around religious matters! Finally, Ben-Ur misses the ironic fact that the nineteenthcentury turn against discrimination (in some forms) was frequently justified 
by religious, even halakhic language, a distinct reversal of the earlier manner in which religion and halakhic worries had justified the marginalization of those who were not purely white. ${ }^{34}$

The double face of slavery shows itself everywhere. Ambiguity, complexity, diversity, all characterized daily life in slave societies; love and loyalty across racial lines, humane masters and whites, slaves and freed slaves assembling and wielding some elements of power over their own lives. But until abolition, as Hannah Arendt wrote, "slavery remained the social condition of laboring no matter how many slaves were emancipated."35 Samuel Nassy, seventeenthcentury community leader in Suriname and son, supposedly kabbalisticallyinclined, of active colonialist David Nassy, also allegedly kabbalistically-inclined due to the influence of their teacher Rabbi Isaac Aboab da Fonseca, operated a plantation with close to two hundred slaves. Davis makes these white Sephardic men the central figures in her meditation on Jewish inclusiveness of slaves. That seventy slaves ran away from Samuel's plantation in 1680, that in 1690 an uprising of slaves on another Sephardic plantation saw the slaves killing their owner, does not inspire in me much confidence about the meaning of Jewish inclusiveness toward slaves. ${ }^{36}$

In this regard, Davis's "imagined" Passover Seder in Suriname, at the end of her essay on the Nassy family, disappoints bitterly, turning from her usual analytic rigor to a rhetorical form closer to fiction. Yes, she wonders whether some of the slaves belonging to Jews might have wished to be back in their own home in Africa. But regarding the masters, "Some Jewish [slave] owners, reciting 'The Egyptians treated us badly, they made us suffer,' may have resolved not to do the same to the slaves on their own lands." ${ }^{37}$ Note the subjunctive case, but also that only the suggestive positive possibility is offered, not the negative possibility of the kind of compartmentalized mental space so ubiquitous in those slave-dependent centuries among Europeans of all denominations, nor the possibility of utter hypocrisy.

The continued rhetorical downplaying by Jewish scholars of the ugly sides of Jewish involvement in the slave system disheartens me. Very few seem willing to acknowledge in analytically significant ways, much less to focus on, the harsh, exclusionary, racialist behavior and attitudes of Jews toward blacks and mixed-race people in the Atlantic world. This aversion, intentional or unconscious, reflects some of the problems of identity politics even among

34 This was true in Barbados as well (Watson, "Shifting Identities," 220-21).

35 Hannah Arendt, The Human Condition (Chicago: University of Chicago Press, 1958), 217.

36 Davis, "Regaining Jerusalem," 32 and n. 76.

37 Davis, "Regaining Jerusalem," 38. 
sophisticated, supposedly critical scholars and the tempting ties of solidarity between scholarship of ethnicities and those ethnic communities. I understand why polities find it hard to acknowledge their failings and to engage in self-criticism. I cannot understand why it should remain so difficult for criticalminded scholars to do so.

A few examples from the religious sphere should suffice to show how easily relevant documents continue to confound scholars and feed questionable readings. It seems possible that a new blessing for the purchase of a slave was penned in the seventeenth century, as I had noted in Jews and Blacks in the Early Modern World. Davis cites it as evidence for the continued conversion of slaves. The siddur put out by Isaac de Mattathias Aboab in 1687, approved by Rabbi Isaac Aboab da Fonseca, has the ritual for circumcising a male slave, ritually immersing a female slave, and a blessing for purchasing a slave for which I was not able to find any halakhic precedent: ${ }^{38}$

Master of this slave, take kind pity and remember to rejoice in his works and to enslave him and his children after him, as it says [Lev. 25:46], you may keep them as a possession for your children after you, for them to inherit as bondsmen for all time. Blessed are You, Lord, who are good and does good.

It could be that this text was written in response to the continued reality of slavery among Sephardim. Yet this is a questionable text to use as proof of inclusion of slaves into Judaism, since it specifically takes the harsher stance, held by many rabbis in the Atlantic world, that it is a positive commandment never to free slaves like the one just bought! Supposedly showing that Sephardim continued to make their slaves Jewish, and treated them kindly, this same text would then have to be read as halakhically forbidding manumission! Is "Judaism" here interpreted as inclusive or tyrannical? It could be both, of course, and that is why investigators then need to provide explanations for the internal discursive contradictions and social/theo-political fault lines.

Another example: In 1767/68, Selomoh Levy Maduro of Curaçao reprinted a pamphlet on circumcision, Brit Yitzhak, that, as I read it, intentionally dispensed with the need for Jews to circumcise their male slaves by relegating the blessing to times when the Jerusalem Temple existed. Brit Yitzhak was (first?) published in Amsterdam in 1729 by Hakham Yitzhak b. Moshe Lopes Pereira,

38 Isaac de Mattathias Aboab, ed., Seder Berakhot. Orden de Bendiciones y las ocaziones en que se deven dezir (Amsterdam: Albertus Magnus, 5447(1686/1687), 184; Davis, "Regaining Jerusalem," 27-28; Schorsch, Jews and Blacks, 155, 412, n. 115. 
with the gentleman (gvir) Yitzhak Yehuda Leon Temple and the physician Daniel b. Avraham Pereira. Importantly, as the text states (but Ben-Ur never mentions), the book reflects practice in Israel and Turkish lands, whose slavery differed vastly from that of the Atlantic world. In several essays, Ben-Ur cites this text as proof of inclusion of slaves in Judaism, since the blessing to be said for circumcising slaves is retained. ${ }^{39}$ As with my first example, what needs to be explained is not the continued appearance of blessings regarding slaves, since conservative religious instincts meant that ritual texts rarely disappeared without good reason. But let us say that I am wrong; perhaps this later edition was used in the Atlantic world for circumcision of slaves, only without a blessing. As I proved already, however, a surprising number of prayer books dropped this blessing and the ritual for slaves in the seventeenth century and it is this jettisoning that requires explanation. ${ }^{40}$ It is the patent dropping of ritual texts pertaining to slaves that begs for elucidation. We might be left, then, with conflicting attitudes even among the religious leadership toward the circumcision of slaves.

More strangely, however, Ben-Ur cites this text to prove circumcision of slaves while quoting the blessing itself, which includes the line, "He that is born in thy house and he that is bought with thy money, must needs be circumcised," ${ }^{\prime 1}$ despite the fact that-as she knows-the historical record shows quite clearly that only some slave boys born to Sephardic slave owners were circumcised and overwhelmingly not slaves who were purchased (i.e., "bought with thy money"). None of the new research has offered evidence to make me change my opinion concerning this. How odd, then, to cite a passage in a prayer book to prove that Jews observed one part of a commandment when the passage cited proves that Jews failed to observe another part of the same commandment. Again, the scholar must ask why and offer some discussion. Is the practice a matter of ethnic ties, as Ben-Ur herself argues? Then why cite a halakhic text to bolster non-halakhic practices?

Moses Levij Maduro (c. 1709-1766), possibly our author's father, was the lover and protector of the "free negress" Mariana Franko. She was employed at the Sorgvliet plantation, owned by the Lamont family. She got into trouble with the authorities for a crime she says she did not commit. All this c. $1760 .^{42}$ Is it

39 Ben-Ur, cites this text in "Peripheral Inclusion," 189.

40 Schorsch, Jews and Blacks, chap. 7. I can add one more title to this list: Yosef Gallego, Imrei No'am (Amsterdam: Menasseh b. Yosef b. Yisrael, 1628), 78a-81b, has the ceremony for a brit, but no mention of slaves anywhere. Gallego was a hazan (cantor)from Salonica.

41 Trans. in Ben-Ur, "Peripheral Inclusion," 189.

42 See Han Jordaan, "Free Blacks and Coloreds and the Administration of Justice in Eighteenth-Century Curaçao," NWIG 81, nos. 1-2 (2010): 72-76. The Selomoh L. Maduro 
possible that our author Selomoh's stance against bringing slaves into Judaism was influenced by what he saw as his own ancestors' too open comportment with non-whites?

Even as fine a scholar as Davis unfortunately falls into this pattern. Despite the fact that Pardo recommended in 1689 that plantation owners "complete" the African circumcisions of their slaves, by taking a drop of blood, as halakhically required, this does not tell us that slave-owners did this. No circumcision manual or prayer book that I know of reflects his suggested approach, though it existed since tannaitic times (it is cited in a baraita in the Babylonian Talmud, Shabbat 134b, among other rabbinic texts). Indeed, Pardo probably came up with this suggestion precisely because slave owners were not circumcising their slaves. Davis cites one 1732 report from a slave, born around 1700, that he had been born on a Jewish plantation and was circumcised on the eighth day. He was sold at eighteen years old when his master died. ${ }^{43}$ Note that this case does not prove that any slave owner followed Pardo's ruling. But it does show the difficulties of using such evidence as proof of Jewish beneficence, since the slave was sold despite having allegedly undergone the sacred ritual marking that made him Jewish! It was precisely to prevent such a transgression against rabbinic law that the Recife Mahamad issued an ascama in 1649 ordering circumcisions to be carried out only after a male slave had been freed. So on the one hand we have the master's supposed punctiliousness and inclusiveness, while on the other the callousness of the sellers, who could well have been members of the master's own family.

Not another example of positive evidence has surfaced that Jewish masters regularly circumcised or immersed or drew a drop of blood from slaves despite the experiences of hundreds of Jewish slave owners with thousands upon thousands of slaves, from several colonies, over the course of several centuries. Let me be clear: obviously some masters must have conducted these rituals. That is not the point. The point is the analytical leap from a small number of exceptions to concluding a general inclusiveness on the part of Jews toward their slaves. This strikes me as wholly unwarranted. Those who make such a leap are guilty of projection rather than reading of the evidence.

A review of the relevant communal ordinances from around the Sephardic Atlantic will allow us to continue the discussion on another level and address the contradictions I have raised.

whose ownership of a plantation in 1722 I mentioned in my book is more likely our author's grandfather, possibly Salomon (Ribi) Levy Maduro (1690-176o).

43 Davis, "Regaining Jerusalem," 30; Jan Willem Kals, Neerlands Hooft-en Wortel-sonde, het Verzuym van de Bekeeringe der Heydenen (Leeuwarden: Pieter Koumans, 1756), 51. 
Ascamot, Amsterdam:

- 1614: separate section in cemetery established "especially for the burial of slaves, servants and 'Jewish girls, who are not of our Nation."

- 1627: "No black person nor mulatto will be able to be buried in the cemetery, except for those who had buried in it a Jewish mother [...] none shall persuade any of the said blacks and mulattos, man or woman, or any other person who is not of the nation of Israel to be made Jews."

- 1641: Mahamad orders that Sephardic women not send their black and mulatto girls (servants or slaves) to reserve seats for them in the synagogue's women's gallery; also that the doors to the women's section of the sanctuary were not to be opened before six in the morning, in order to prevent the "unseemly" congregating of these women and other servants on the street.

- 1644: "circumcised Negro Jews" were not to be called to the Torah or given any honorary commandment to perform in the synagogue, "for such is fitting for the reputation of the congregation and its good government."

- 1647: separate section of the cemetery is established for "all the Jewish blacks and mulattos." Exceptions limited to those "who were born in Judaism, [their parents] having [been married] with quedo$\operatorname{sim}$ [with kiddushin, i.e., properly, according to Jewish law], or those who were married to whites with quedosim."

- 1650: "Renewal of the ascama of 1639 which treats the circumcising of goyim. The Gentlemen of the Mahamad declare that the same penalty of herem [the most stringent form of excommunication] [will apply] to any [person] circumcising blacks or mulattos and also any immersing them or [any who] should be a witness for them [as required by halakha-JS], seeing [their] immersing, or [that of] any other person or woman who is not of our Hebrew nation. The Gentlemen of the Mahamad, having some occasion of a son or daughter of a Jew who should come to the [ritual] bath or give birth [?] [and] who should be raised in his house with his [word unclear] may arrange [to do] as he sees fit."

- 1658: mulatto (and tudesco) boys no longer be admitted for study in the Amsterdam yeshiva of the Sephardim

Ascamot, Suriname:

- 1663 or 1665 : the leadership decides to demote the status of jehi$\operatorname{dim}$ [full members] who marry a mulatta; a jahid [full member] is 
prohibited from circumcising sons born to jehidim who had been demoted to congreganten. The penalty for doing so is herem.

- 1734: Mulatto Jews in Jodensavanne "may not have any Mitsvahs on Holiday or Sabbath days, but only on rosh hodesh [the New Moon] and the minor fasts and are also required to sit behind the teva [the central table whence prayers were led and the Torah read]."

- 1754: "[S]ince experience has taught how prejudicial and improper it would be to admit Mulattos as jehidim [full members], and noting that some of these have concerned themselves in matters of the government of the community, it is resolved that henceforth they will never be considered or admitted as jehidim and will solely be congreganten, as in other communities."

- Members who married a mulatto woman, "either according to our Holy Law or solely in front of the Magistrates," would have their children considered mulattos by the community as punishment.

- Non-white Jews had to sit at the bench of mourners, located at the synagogue's margin.

- Non-white Jews could not receive certain public blessings (mi-she-berakh).

- No woman who was black, mulatto or Indian could enter the prayer hall, not even to tend to her master's children, "considering the Respect of the Holy Place."

By the 1780 s the ascamot accept as congregantes any colored children "who carry the name of, or are known to be descended of the Portuguese or Spanish Nation."

- 1787: further exclusive ascamot, including distinctions between the various categories: karboeger (black and mulatto), mulatto (black and white), mestice (white and mulatto), castice (white and mestice).

- 1794: resolution that jehidim who tried to sit in the seats for congreganten or have congreganten sit next to them in seats reserved for jehidim would be fined one hundred guilders. ${ }^{44}$

- 1797: jehidim cannot sit at the bench for born congreganten behind the teva and the bench in front of the seat of the samas. ${ }^{45}$

44 Ben-Ur, "Peripheral Inclusion," 196, reads this as evidence that some jahidim may have tried to sit with their mixed-race family members.

45 Ibid., reads this as evidence that some jahidim who were demoted from their status for having married a non-white sat with those who had been born as congreganten because of their mixed-race status. 
Ascamot, Curaçao:

- 1702: "women other than the Brides of the Law or of a Marriage, together with their bridesmaids" are barred from sitting "in the front part of the ladies' gallery" of the synagogue.

- 1751: order "not to bring into the synagogue black or mulatto women in order not to remove the devotion which there needs to be."

- 1754: lending money at interest to slaves and whites is forbidden, but Jewish law permits taking interest from free blacks.

This list is not fully complete, it leaves out relevant ordinances from Dutch Brazil, London, and elsewhere, while also ignoring de facto practices—such as a door for blacks (Porta dos negros) in the Jodensavanne synagogue-but hopefully it gives a good sense of the sweep of the legislation that blackness engendered in the Sephardic Atlantic. ${ }^{46}$

If these rules revolve solely around the religious congregation, that is because in Amsterdam it was actually the Spanish and Portuguese Jewish community that initiated racial legislation there and they were concerned to create order within their own sphere, while in the colonies the basic racial laws were already laid down by the colonial authorities.

This list makes it easier to see the question of religion and culture in a more precise manner. What role did Judaism play in all of this? What was its relationship to the increasingly racialized societies of the Americas? Here, too, ambivalence and doubleness mark everything. The ordinances waver between halakhic concerns and social/racial ones, as well as between metropolitan and colonial exigencies. In Amsterdam, the metropole, communal leaders found the Judaizing of non-whites undesirable and legislated against it. The first Surinamese ascama did likewise. On Curaçao the prohibition was unwritten. Despite this, Surinamese masters and the community leadership preferred the communal benefits of additional bodies and the psychological rewards of personal procreative self-expansion.

To this we can add what we know of religious factors that do not appear in communal legislation. The very proliferation of mixed-race children shows that Sephardic men were ignoring halakha and rulings forbidding masters to have sex with slave women. With extremely few exceptions, neither community leaders nor rabbis seem to have complained about this or sought to stop it. ${ }^{47}$ Sephardim ceased manumitting slaves according to halakha, now following

46 Sources can be found in Schorsch, Jews and Blacks, chap. 8, Vink, Creole Jews, as well as in Ben-Ur's studies.

47 I can find only a single case of a rabbi chastising plantation owners for this. Abraham Gabay Yzidro, a conservative figure, who became embroiled in a raging battle against the 
general secular practice and civil law. Manumission of slaves was rare, and it seems that many individuals and communities in the colonies followed, at least de facto, the halakhic opinion that slaves were never to be manumitted. ${ }^{48}$ In these last three cases, then, "religion" had yielded to or supported common practice that in some sense brought advantage: sexual satisfaction, freedom from the burdens of halakhic regulation of slaves, expanded family, economic gain, extended service from slaves. The one relevant halakha that Surinamese Sephardim seem to have followed is letting their slaves rest on Shabbat, the Jewish Sabbath day.

The not surprising conclusion is that the distance maintained by Sephardim in the Caribbean between their religion and their slaves derived from antiblack sentiments and societal objective correlatives-near exclusive reliance on black and colored labor, social, cultural, and economic denigration and exclusion of non-whites-both in the Christian Americas and in Sephardic Amsterdam. I have not come across any explicit communication between the Amsterdam Sephardic leadership and any of the colonial Sephardic congregations regarding slave policy, but there can be no doubt that the written

Jodensavanne parnassim when he was rabbi there in the 1730s, lambasted his enemies for their "ease with women" (facilidad con mujeres) and "evil passions" (negras pasio$n e s$ ), the Spanish pun making it likely that he had slave women in mind (Stadsarchief Amsterdam, inv. nr. 1029, 30; Jonathan Schorsch, "Abraham Gabay Yzidro: A Rabbi Navigating the Eighteenth-Century Atlantic World" [forthcoming]). Such transgressions had led Maimonides to rule that a master who had sex with his slave woman must either free, convert and marry her, or remove her from his possession (Yehoshua Blau, ed., Responsa of Rambam [Hebrew], 3 vols. [Jerusalem: Mekitzei Nirdamim, 1958], no. 211). But frequently Surinamese Sephardic planters did not free their slave women, even when freeing and making Jewish the children they bore from them. As proof of the fact that Sephardic Surinamese converted their mixed-race children, Ben-Ur cites the will of the planter Isaac da Costa (d. 1734), whose six mulatto children by various slave women all were made or chose to become Jewish. But his will, by leaving out any statement of the mothers' Jewishness, seems to indicate that Da Costa did not convert any of these slave women themselves; that is why if this slave-owning patriarch wanted his children to be Jewish he had to have them made Jewish through ritual (Ben-Ur, "Cultural Heritage," 183). See also the list of births, "Registro de Notaçaõ dos nacimentos do K.K. Beraha Ve-Salom," beginning 1777, Nationaal Archief (The Hague), Port.-Israel. Gemeente, no. 417, which lists many mothers of children made Jewish who themselves were neither manumitted nor converted. The question of slave women and sex is extremely complicated; for a good general overview, see Yaron Ben-Naeh, "'And You Will Have a Maidservant Forever', Slavery and Slaves in Ottoman Jewish Society," [Hebrew] Ha-Mizrah Ha-Hadash 50 (2011): 79-82.

48 To add findings from the recent research, on Barbados, the 98 extant eighteenth-century wills mentioning specific bequests inform us that, while Sephardic Jews ordered manumission of their slaves on three occasions, $5^{1}$ Sephardic Jews bequeathed slaves as property to others, usually family members (Watson, "Shifting Identities," 201). Out of Jamaican wills between 1673 and 1814, "the manumission of slaves was stipulated in only twenty-nine-under 12 per cent" (Mirvis, "Sexuality and Sentiment," 229). 
and unwritten slave policies of the Caribbean communities followed those of Amsterdam in letter and in spirit and then added to them based on local, colonial configurations. As in Amsterdam, in Suriname a group of colored Jews arose and became large enough to cause community leaders discomfort. As did Christian attitudes, Sephardic attitudes hardened over time with the mushrooming of a mostly African, often hostile, slave population. These antiblack phobias made for some strange bedfellows, such that groups that became marginalized in white, Christian Europe and neo-Europe often partook in them as a means of shoring up their own noble self-image. The well-known Inca author Felipe Guaman Poma de Ayala writes, ca. 1616, that "If [an Indian woman] marries a black man (whether slave or free) who has received God's curse, she becomes a slave and a black woman like her husband." ${ }^{49}$

By design, community leadership in the Western Sephardic diaspora came to reside almost entirely in the hands of the wealthy elite, through the Mahamad. In 1639, the three newly-combined Amsterdam Spanish and Portuguese communities issued a series of communal ordinances prescribing in many respects how the community was to function. The ninth ordinance stipulated that community leaders and judges should follow, except where it will conflict with Torah, mercantile law or the law merchant. ${ }^{50}$ This formulation gives remarkable power to an essentially secular regime, standing outside of the religious law. This state of affairs has long been known to scholars. As Jonathan Israel put it, "major decisions affecting the life and dealings of the community were made by men who were deeply involved in international trade and finance, acutely sensitive to the intricacies of great power politics, rather than based purely on religious law and rabbinic tradition."51 This power dynamic is reiterated in a first-person description from $165^{\circ}$ by R. Shmuel Aboab: "There is a minority of places where those parnassim who are elected to lead the congregation and are already accepted by them judge the people and they sometimes, according to the nature of the matter, consult with the Rabbi who disseminates Torah among them and they ask of him his opinion regarding that law and they do fittingly by doing so and this is the quality of humility and fear of sin."52 Religious law here serves an ultimately advisory role, as was typical among

49 Felipe Guaman Poma De Ayala, First New Chronicle and Good Government, Abridged, trans. and ed. David L Frye (Indianapolis: Hackett Publishing, 2006), 159.

$5^{0}$ Quoted in Yosef Kaplan, "Eighteenth-Century Rulings by the Rabbinical Court of Amsterdam's Community and Their Socio-Historical Significance" [Hebrew], Studies on the History of Dutch Jewry, ed. Jozeph Michman, 5 vols. (Jerusalem: Magnes Press, 19751988), $5: 3$.

51 Jonathan I. Israel, Diasporas within a Diaspora:Jews, Crypto-Jews and the World Maritime Empires, 1540-1740 (Leiden: Brill, 2002), 78.

$5^{2}$ Quoted in Kaplan, "Eighteenth-Century Rulings," 4. 
the Western Sephardim who derived from Spain and Portugal, but contrary to the generally rabbinical leadership among Eastern Sephardic communities. ${ }^{53}$ That the leaders inquire of the rabbi is a courtesy, not a necessity.

None of the numerous ascamot excluding non-whites was promulgated by a rabbi! Sephardic rabbis in the Atlantic world, when they discussed slavery at all, mostly leaned toward full inclusion in accord with halakha, though this often meant forbidding manumission. Contra Ben-Ur, then, "Judaism" included and excluded non-whites in the Atlantic world in some ways, while "Jewish civilization" moving toward secularization included and excluded them in other ways. Ben-Ur and I agree that the decision-making of the parnassim adjusted Judaism to fit current realities as they saw them. It is not surprising that Sephardic law regarding slaves did not reflect halakha, since the Western Sephardic communities, in some cases because of the Christian upbringing of these formerly-converso "New Jews," had an ambivalent relationship with rabbinic halakha. On the one hand, the communities were officially religious and infractions of religious law were punished. On the other hand, individual observance and practice deviated widely. It is not surprising that most of the individuals who settled the colonies were not particularly observant.

When it comes to mixed-race Jews, Ben-Ur, following the sociological approach of Arnold Eisen, wants to distinguish between what Jews "do" and what they "believe," arguing that only the former should be taken seriously by scholars. ${ }^{54}$ This is an ironic stance to maintain, since much of what white Sephardim did throughout the Atlantic world was to exclude and marginalize non-white Jews - and even more non-white non-Jews - the leadership through official legal ordinances and repeated political efforts to maintain such laws, and much of the Sephardic population by voluntarily or reluctantly adhering to the racialized laws and social structures, which it did with few exceptions. Here, once again, the question is which Jews did what and why.

The responses of the ruling elite still require more nuanced unpacking. Let me return to Moisés de Mesquita. What exactly accounts for the difference between the openness of the merchants in Senegal, the intolerance of

53 Yosef Hacker, "The Jewish Independent Judiciary in the Ottoman Empire in the 17th and 18th Centuries: The Boundaries of Autonomy" [Hebrew], Transition and Change in Modern Jewish History: Essays Presented in Honor of Shmuel Ettinger, ed. Shmuel Almog et al. (Jerusalem: Historical Society of Israel/Zalman Shazar Center, 1987), 353.

54 Ben-Ur, "Cultural Heritage," 19o. She asserts that looking through the lens of religion alone "distorts the picture of what many Jewish slave masters attempted to do when they included slaves in their household" (192), but it is not clear to me through her interpretation what they "attempted to do." Much of the relevant documented language about slaves and mixed-race Jews is religious language or language about religion, while the actual behavior of Jews was at least as often exclusive as inclusive. 
the Amsterdam parnassim, and the ambivalently open parnassim in Suriname makes a good topic for further study. As Mark and Horta show, local attitudes of course play a major role. Green speculates that "Where there were very few Jews, or even crypto-Jews, assimilation into the dominant cultural praxis was an obvious choice. ${ }^{55}$ I suspect that it is more complicated than this. The distinction clearly was not merely economic, a divergence of opinion between elites and commoners. ${ }^{56}$ Are those individuals adventurous enough to travel overseas and engage with foreign, exotic societies and cultures already inclined to "mixing," to acceptance of the Other? Does the travel and immersion itself shape their openness? ${ }^{57}$ Experiences in Africa, Asia, or the colonies hardly produced monolithic responses, however, so individual subjectivities and different kinds of experiences keep us guessing about the mix of causal factors in racial attitudes. Some of the parnassim ruling against the inclusion of non-whites were themselves overseas merchants; some had lived in western Africa or Brazil or lived in the colonies themselves.

Furthermore, we have to keep in mind the often tenuous religiosity or loyalty to rabbinic Judaism evinced by many of the "New Jews" in the Western Sephardic communities of the seventeenth century; as Green continues, those Sephardim (he is actually discussing New Christians, but I want to shift the question) who wanted to be "good Jews" went to the major cities, North Africa or Ottoman lands. ${ }^{58}$ Does this imply that those Sephardim who went to West Africa or the Caribbean cared less to begin with about proper Judaism? This would be a rash but plausible generalization.

Contrarily, are the parnassim reflecting the conservatism of the homebound? Are parnassim elected precisely because they evince a sober, conservative orientation? It could be that issues besides race were at work here. The emphasis that the relatively young Amsterdam community placed on legal and ritual adherence to rabbinic Judaism, given its many members who had been raised as Catholics, is well known. When we get to the parnassim in the colonies, we have a different situation. In Surinamese Jodensavanne these were almost all plantation owners, some open to certain kinds of relationships with non-white Jews. Ben-Ur tries to dissect some of the dissenting views of the parnassim toward mixed-race Jews in the late eighteenth century, but without conclusive results. Certainly divergences between metropole and colony

55 Green, "Equal Partners?," 7.

56 As I erroneously speculated in Schorsch, Blacks and Jews, chap. 8.

57 Green rightly thinks that "personal experience was crucial" ("Amsterdam and the African Atlantic," 93).

$5^{8} \quad$ Green, "Equal Partners?," 7. 
play a key role. Likely, in general, parnassim cared more about the importance of conformity than peripatetic merchants. Perhaps being appointed parnas pressured one, almost structurally, to defend communal norms and perceived honor. Better answers will come from more careful analysis.

Bom Judesmo, the Western Sephardic ideal, was both upheld and subverted by slavery and race. It was upheld insofar as its noble self-image and disciplinary mechanisms were reinforced by the exclusion of lower Others such as slaves and non-whites. It was subverted insofar as this exclusion contradicted its ostensibly halakhic standards, generating an internal subaltern group that understood its exclusion and denigration to be against the very religious principles of the community. One need look no further than the name of the society formed by and for the colored Jews of Suriname, Darhe Jesarim (Paths of the Upright).

In short, we must reconsider the conclusion of the great historian Salo W. Baron. He wrote that "Neither the slave trade, therefore, nor slaveholding seems ever to have been so important a factor in Jewish economic life. ${ }^{n 9}$ While for Jewish history as a whole he is undoubtedly correct, for the early modern Atlantic world, over the course of two or three centuries several Jewish communities in the Americas depended on and participated actively in the general slave economy. Beyond economics, the presence of non-whites and slaves in a number of Sephardic communities was significant enough to influence communal legislation. Slavery and race acted together as forces that helped push Sephardim away from halakha and toward secular law and what we now call cultural Jewishness beginning in the seventeenth century. They functioned as pressures "modernizing" Western Sephardim along an alternative path rather before the Enlightenment, as Yosef Kaplan has discussed. Obviously this particular path of modernization should strike us as paradoxical, if not perverse; yet so it was, as David Brion Davis noted long ago in his path-breaking analysis of Jews and slavery. ${ }^{60}$ Even into the twenty-first century, black and mixed-race Jews have challenged Bom Judesmo for recognition and inclusion, to unfortunately unimpressive degrees of success.

59 Salo Wittmayer Baron, A Social and Religious History of the Jews, 18 vols. (New York/ Philadelphia: Columbia University Press/Jewish Publication Society of America, 195283), 4: 196.

6o David Brion Davis, Slavery and Human Progress (New York: Oxford University Press, 1984), chap. 6 ("Jews and the Children of Strangers"). 


\section{Bibliography}

Aboab, Isaac de Mattathias, ed. Seder Berakhot. Orden de Bendiciones y las ocaziones en que se deven dezir. Amsterdam: Albertus Magnus, 5447[1686/1687].

Arendt, Hannah. The Human Condition. Chicago: University of Chicago Press, 1958.

Ayala, Felipe Guaman Poma de. First New Chronicle and Good Government, Abridged. Translated and edited by David L Frye. Indianapolis: Hackett Publishing, 2006.

Baron, Salo Wittmayer. A Social and Religious History of the Jews. 18 vols. New York/ Philadelphia: Columbia University Press/Jewish Publication Society of America, 1952-83.

Barringer, Tim, Gilliam Forrester and Barbara Martinez-Ruiz, eds. Art and Emancipation in Jamaica: Isaac Mendes Belisario and His Worlds. New Haven: Yale University Center for British Art/Yale University Press, 2007.

Ben-Naeh, Yaron. 'And you will have a maidservant forever.' Slavery and Slaves in Ottoman Jewish Society." [Hebrew] Ha-Mizrah ha-Hadash 50 (2011): 66-9o.

Ben-Ur, Aviva. "A Matriarchal Matter: Slavery, Conversion, and Upward Mobility in Suriname's Jewish Community." In Atlantic Diasporas:Jews, Conversos, and CryptoJews in the Age of Mercantilism, 1500-180o. Edited by Richard L. Kagan and Philip D. Morgan, 152-69. Baltimore: Johns Hopkins University Press, 2009.

Ben-Ur, Aviva. "Peripheral Inclusion: Communal Belonging in Suriname's Sephardic Community." In Religion, Gender, and Culture in the Pre-Modern World. Edited by Alexandra Cuffel and Brian Britt, 185-210. New York: Palgrave Macmillan, 2007.

Ben-Ur, Aviva. "Still Life: Sephardi, Ashkenazi, and West African Art and Form in Suriname's Jewish Cemeteries." American Jewish History 92, no. 1 (2004): 31-79.

Ben-Ur, Aviva. "The Cultural Heritage of Eurafrican Sephardi Jews in Suriname." In The Jewish Diaspora in the Caribbean. Edited by Jane S. Gerber, 169-93. Oxford: Littman Library of Jewish Civilization, 2013.

Ben-Ur, Aviva, and Jessica Vance Roitman. "Adultery Here and There: Crossing Sexual Boundaries in the Dutch Jewish Atlantic." In Dutch Atlantic Connections, 1680-180o: Linking Empires, Bridging Borders. Edited by Gert Oostindie and Jessica V. Roitman, 185-223. Leiden: Brill, 2014.

Blau, Yehoshua, ed. Responsa of Rambam. [Hebrew] 3 vols. Jerusalem: Mekitzei Nirdamim, 1958.

Davis, David Brion. Slavery and Human Progress. New York: Oxford University Press, 1984.

Davis, Natalie Zemon. "Creole Languages and Their Uses: The Example of Colonial Suriname." Historical Research 82, no. 216 (May 2009): 268-84.

Davis, Natalie Zemon. “David Nassy's 'Furlough' and the Slave Mattheus.” New Essays in American Jewish History, Commemorating the Sixtieth Anniversary of the Founding 
of the American Jewish Archives. 79-93. Cincinnati: American Jewish Archives, 2010.

Davis, Natalie Zemon. "Judges, Masters, Diviners: Slaves' Experience of Criminal Justice in Colonial Suriname." Law and History Review 29, no. 4 (November 2011): 925-84.

Davis, Natalie Zemon. "Regaining Jerusalem: Eschatology and Slavery in Jewish Colonization in Seventeenth-Century Suriname." The Cambridge Journal of Postcolonial Literary Inquiry 3, no. 1 (January 2016): 11-38.

Gallego, Yosef. Imrei No'am. Amsterdam: Menasseh b. Yosef b. Yisrael, 1628.

Green, Tobias. "Amsterdam and the African Atlantic: The Role of Amsterdam Sephardim in Senegal in the Early Seventeenth Century." Proceedings of the Fourteenth British Conference on Judeo-Spanish Studies (26-28 June 20o6). Edited by Hilary Pomeroy, Christopher J. Pountain and Elena Romero, 85-94. Dept. of Hispanic Studies, Queen Mary, University of London, 2008.

Green, Tobias. "Equal Partners? Proselytising by Africans and Jews in the 17th-Century Atlantic Diaspora." Melilah 1 (2008): 1-12.

Green, Tobias. "Masters of Difference: Creolization and the Jewish Presence in Cabo Verde, 1497-1672." PhD diss. Centre of West African Studies. University of Birmingham, 2006.

Green, Tobias. The Rise of the Trans-Atlantic Slave Trade in Western Africa, 1300-1589. Cambridge: Cambridge University Press, 2011.

Hacker, Yosef. "The Jewish Independent Judiciary in the Ottoman Empire in the 17th and 18th Centuries: The Boundaries of Autonomy." [Hebrew] In Transition and Change in Modern Jewish History: Essays Presented in Honor of Shmuel Ettinger. Edited by Shmuel Almog et al., 349-88. Jerusalem: Historical Society of Israel/The Shazar Center, 1987.

Idelson-Shein, Iris. Difference of a Different Kind: Constructions of Race During the Long Eighteenth Century. Philadelphia: University of Pennsylvania Press, 2014.

Israel, Jonathan I. Diasporas within a Diaspora:Jews, Crypto-Jews and the World Maritime Empires, 1540-1740. Leiden: Brill, 2002.

Jordaan, Han. "Free Blacks and Coloreds and the Administration of Justice in Eighteenth-Century Curaçao." NWIG 81, nos. 1-2 (2010): 63-86.

Kals, Jan Willem. Neerlands Hooft-en Wortel-sonde, het Verzuym van de Bekeeringe der Heydenen. Leeuwarden: Pieter Koumans, 1756.

Kaplan, Yosef. "Eighteenth-Century Rulings by the Rabbinical Court of Amsterdam's Community and Their Socio-historical Significance." [Hebrew] In Studies on the History of Dutch Jewry. 5 vols. Edited by Jozeph Michman, 5: 1-54. Jerusalem: Magnes Press, $1975^{-1988 .}$

Mark, Peter, and José da Silva Horta. "Catholics, Jews, and Muslims in Early SeventeenthCentury Guiné." In Atlantic Diasporas:Jews, Conversos, and Crypto-Jews in the Age of 
Mercantilism, 1500-180o. Edited by Richard L. Kagan and Philip D. Morgan, 170-94. Baltimore: The Johns Hopkins University Press, 2009.

Mark, Peter, and José da Silva Horta. The Forgotten Diaspora: Jewish Communities in West Africa and the Making of the Atlantic World. New York: Cambridge University Press, 2011.

Mirvis, Stanley. "Sexuality and Sentiment: Concubinage and the Sephardi Family in Late Eighteenth-Century Jamaica." In The Jews in the Caribbean. Edited by Jane S. Gerber, 223-40. Oxford: Littman Library of Jewish Civilization, 2011.

Ranston, Jackie. Belisario: Sketches of Character: A Historical Biography of a Jamaican Artist. Kingston: The Mill Press, 2008.

Schorsch, Jonathan. Jews and Blacks in the Early Modern World. New York: Cambridge University Press, 2004.

Tavim, José Alberto Rodrigues da Silva. "Galut and Empire: On the Way to the Final Redemption." In The Sephardic Atlantic: Colonial Histories and Postcolonial Perspectives. Edited by Sina Rauschenbach and Jonathan Schorsch. New York: Palgrave, forthcoming.

Vink, Wieke. Creole Jews: Negotiating Community in Colonial Suriname. Leiden: KITLV Press, 2010.

Watson, Karl. "Shifting Identities: Religion, Race, and Creolization among the Sephardi Jews of Barbados, 1654-1900." The Jews in the Caribbean. Edited by Jane S. Gerber, 195-222. Oxford: Littman Library of Jewish Civilization, 2011. 